\title{
VOLUNTEER ACTIVITIES IN THE WORK SYSTEM ON FORMING PROFESSIONAL AWARENESS OF CORRECTIONAL EDUCATOR
}

\section{Tetiana Kuznetsova ${ }^{1}$ Maryna Omelchenko ${ }^{2}$}

\author{
DOI: https://doi.org/10.30525/978-9934-26-050-6-47
}

Reforming special education in Ukraine is aimed at identifying new priorities and prospects for developing the special school, improving the process of education and upbringing of children with special educational needs, developing new technologies for pedagogical correction of their violations. New trends are being traced in forming the personality of the correctional educator, who should become the conductor of modern ideas of the New Ukrainian school. To meet modern professional requirements, correctional educators must constantly engage in self-education and selfimprovement of their professional skills and abilities, develop professional awareness, which directly determines the effectiveness of professional activities. They acquire initial skills and professional awareness in the institution of higher education when studying theoretical material and participating in their pedagogical practice.

Today in the system of higher education special attention is paid to applying theoretical knowledge in practice, which allows students to acquire professional competencies, professional awareness and immerse themselves in the problems of children with special educational needs. It should be noted that the professional activity of a correctional educator goes beyond the traditional types of teachers' work, since, in addition to teaching and educating pupils, it covers consulting, diagnostic, socio-pedagogical, rehabilitating, psychotherapeutic and correctional activities, as well as implementing measures to prevent and overcome deviations in the child's development and behavior in the educational-upbringing process (S. P. Myronova, O. D. Honieieva). An important component of the educator's professional awareness is the social and emotional component, which contributes to the active civic position, the possibility of constant professional growth, the ability to solve problems that arise before special education [4, p. 13].

For professional growth to be successful, it is important that the correctional educator strives for it, sees it as the main goal. If a specialist has a

\footnotetext{
${ }^{1}$ SHEI «Donbas State Pedagogical University», Ukraine

${ }^{2}$ SHEI «Donbas State Pedagogical University», Ukraine
} 
meaningful idea, goal, plans, then he/she will be able to find ways of professional development, people who will help in this, overcome difficulties, change for the better, progress in his/her professional activities [4, p. 23].

One of the means that can help to solve the problem of forming the professional awareness of a correctional educator, in the authors' opinion, is a volunteer activity. Volunteering encompasses a wide range of activities, such as traditional forms of mutual help and self-help, formal provision of services, and other forms of voluntary civic participation, in particular the provision of assistance to persons with disabilities.

Participation of students in volunteer activity promotes the positive change of communicative awareness and communicative skills, development of empathy, the creative potential of the person, the formation of the social activity directed on change and transformation of the environment [2].

The students of the Faculty of Special Education get acquainted with the form and content of volunteering, learn to work in a team of volunteers using pedagogical technologies in the social sphere, in particular in the educational environment, master group and individual communication techniques, practical skills of correctional and pedagogical technologies in volunteering. They have an additional opportunity to work with children with special educational needs, to help teachers of special educational institutions in promoting the successful socialization of pupils, at the same time they themselves gain practical experience. Students' participation in volunteering creates preconditions for their professional self-determination, provides their self-realization outside the curriculum, expands the boundaries of professional creativity and the formation of professional competencies. The experience gained in volunteering, forms in young people the personality of a caring person who is directly involved in social life, is not afraid of responsibility, is able to work in a team, has a leadership position. All these personal qualities are necessary components of the professional development of a correctional educator.

Volunteering allows students to get acquainted with a wide range of different groups of the population, with different spheres of life, they form a willingness to socio-pedagogical and correctional work with any category of children and adults, to partner with parents of children with special needs, specialists-teachers, employers. The experience that students gain in the process of volunteering contributes to the social and professional development of the future correctional educator.

To create the optimal conditions for forming professional awareness of the students of the Faculty of Special Education of Donbas State Pedagogical University, the educational program includes the subject «Volunteering» and 
the volunteer practice, which allows solving a number of educationalupbringing problems, the main of which are:

- creating the conditions for the activities of student public associations;

- developing all the models of youth self-government and selforganization in student and scientific-academic teams;

- increasing the effectiveness of upbringing work among students;

- creating optimal conditions for joint scientific-research activities of students and lecturers;

- improving orienting professional knowledge, skills, and abilities of students in a practical way on the basis of the university;

- interacting with the media, supporting a positive image of the volunteer in society.

The basis for organizing and conducting work on solving the outlined tasks is creating the Volunteer Resource Center for Inclusion and Psychological and Pedagogical Support for Children with Psychophysical Disabilities at the Faculty of Special Education, whose activities involve lecturers and students. The main directions of the center's work are family counseling on issues of psychological and pedagogical support for children with psychophysical disabilities, providing psychological support for parents and children, conducting correctional classes and workshops for children and parents. On the basis of the Volunteer Center, students have the opportunity to take their pedagogical practice, implement scientific and social volunteer projects. The activity of the Volunteer Center organically coincides with the educational-upbringing process of the faculty, which determines the maximum coverage of students and lecturing staff, which allows forming the professional competencies of the correctional educator. The lecturers have the opportunity to demonstrate by their own example the civic position concerning the state policy on special and inclusive education, ways to solve the problems of institutions of special education, attitudes towards people with disabilities.

At the initiative of the student self-government, the volunteers expand the range of their work, namely, they provide social patronage and provide assistance to special institutions of preschool and school education; pedagogical support for children and adolescents with special educational needs; environmental protection; intellectual development (organizing and conducting intellectual competitions, events among pupils and students); creative development (organizing creative events, competitions, holiday concerts, theatrical performances); promotion of a healthy lifestyle.

Observing the students-volunteers' activities has given the chance to state that besides the general tendency of growth of the indicators of professional awareness, such specific features have been also seen: growth of the level of 
success and independence in studying; changes in attitudes to the professional training; awareness of the professional Self-concept; transformation of positions on the profession of the correctional educator, analysis of its new aspects; growing interest in the problems of special pedagogy and psychology; improving relationships with groupmates.

Thus, organizing student volunteering allows correlating theoretical knowledge with practical skills in solving socio-pedagogical problems and real work for the benefit of society in general and special education in particular.

\section{References:}

1. Gerasimova V. D., Kuzmenko I. V. (2013) Volonterstvo kak faktor razvitiia sotcialnoi kompetentcii studentov vuza [Volunteering as a factor of development of social competence of students of universities]. Uspekhi sovremennogo estestvoznaniia [Advances in Modern Natural Science], no. 10, pp. 174-175. Retrieved from: http://www.natural-sciences.ru/ru/article/view?id=33055 (accessed 27 February 2021).

2. Krutitckaia E. V. (2013) Kompetentnostnyi podkhod k organizatcii volonterskoi deiatelnosti molodezhi $\mathrm{v}$ vysshei shkole [Competence approach to organization of volunteer activity of youth at higher school]. Volonter: Vserossiiskii nauchnoprakticheskii zhurnal [Volunteer: All-Russian Scientific-Practical Journal], no. 1-2, pp. 11-22. Retrieved from: https://unecon.ru/sites/default/files/volonter1-2newred.pdf (accessed 25 February 2021).

3. Lazarchuk L. L. (2007) Volonterskoe dvizhenie $v$ molodezhnoi srede: programmno-metodicheskii kompleks [Volunteer movement among youth: programmethodical complex]. Minsk: BGPU. (in Russian)

4. Omelchenko M. S. (2021) Psykholohiia profesiinoi svidomosti korektsiinoho pedahoha [Psychology of professional awareness of correctional educator]. Sloviansk: Vydavnytstvo B. I. Matorina. (in Ukrainian)

5. Polataiko S. V. (2011) Organizatciia dobrovolcheskoi deiatelnosti v vuze: teoriia i praktika [Organizing volunteer activity in universities: theory and practice]. European Researcher, no. 1(3). (in Russian) 